\title{
Effects of feeding milk replacer at 2 rates with pelleted, low-starch or texturized, high-starch starters on calf performance and digestion
}

\author{
J. D. Quigley, ${ }^{1}$ T. M. Hill, T. S. Dennis, F. X. Suarez-Mena, and R. L. Schlotterbeck \\ Nurture Research Center, Provimi, Brookville, OH 45309
}

\section{ABSTRACT}

Milk replacer (MR) feeding programs have traditionally fed at less than ad libitum amounts to promote calf starter (CS) intake and allow early weaning. More recently, increased amounts of MR preweaning have been shown to increase preweaning ADG, although postweaning growth may be reduced. Several studies suggest that limited postweaning digestion of nutrients in CS may contribute to postweaning growth impairment. It is not clear whether CS formulation might also contribute to differences in postweaning nutrient digestion when calves are fed different MR programs. A 56-d feeding and digestion trial was conducted to compare growth and digestion in 2- to 3 -d-old male Holstein calves ( $\mathrm{n}=48$; initially $41.9 \mathrm{~kg}$ of body weight) fed a moderate (MRM) or high (MRH) MR program and either a pelleted CS containing $9.9 \%$ starch or a texturized CS containing $41.3 \%$ starch. Programs were 0.66 $\mathrm{kg}$ of dry matter $(\mathrm{DM}) / \mathrm{d}$ of MR to d 46 , then $0.33 \mathrm{~kg} / \mathrm{d}$ to d $49(\mathrm{MRM})$ and $0.85 \mathrm{~kg}$ of $\mathrm{DM} / \mathrm{d}$ to $\mathrm{d} 5$, then 1.07 $\mathrm{kg} / \mathrm{d}$ to $\mathrm{d} 42$, then $0.53 \mathrm{~kg} / \mathrm{d}$ to d $49(\mathrm{MRH})$. The MR contained $25 \%$ crude protein and $18.6 \%$ fat and was reconstituted to 13 (MRM) or 15\% (MRH) solids. Calves were also assigned randomly to receive a pelleted CS (9.9\% starch, $36.9 \% \mathrm{NDF})$ or a textured CS $(41.3 \%$ starch, $13.3 \% \mathrm{NDF}$ ) and water for ad libitum intake for $56 \mathrm{~d}$. During d 31 to 35 and 52 to 56 , fecal samples were collected from 5 calves per treatment for estimates of digestibility. Selected nutrients and chromic oxide (d 31-35) or acid-insoluble ash (d 52-56) were analyzed in feed and feces to estimate digestibility. Data were analyzed as a completely randomized design. Repeated measures analysis was performed when data were measured by week. Calves fed MRH gained more body weight (but not hip width) and were more efficient to weaning compared with calves fed MRM, although fecal scores and days treated with medications were greater. We found no effect of CS on animal performance, al-

Received September 18, 2017

Accepted March 3, 2018.

${ }^{1}$ Corresponding author: jquigley@provimi-na.com though calves fed textured CS had higher fecal scores. Digestibilities of nutrients were affected by treatment and time of sampling ( 5 or $8 \mathrm{wk}$ ). At $5 \mathrm{wk}$, digestion of DM, organic matter, crude protein, and fat were lower and digestion of acid detergent fiber, neutral detergent fiber, and starch were higher in calves fed MRM and reflected greater CS intake. Also, digestion of DM, organic matter, acid detergent fiber, starch, crude protein, and fat were greater in calves fed textured CS at 5 wk. By 8 wk, when CS was the only source of nutrients, digestion of DM, organic matter, acid detergent fiber, and neutral detergent fiber were greater in calves fed MRM and digestion of DM and organic matter were greater, and acid detergent fiber and neutral detergent fiber digestion were lower in calves fed textured CS. Formulation of CS as well as amount of MR offered to young calves influenced animal performance and digestion in this study.

Key words: calves, intake, digestion, growth

\section{INTRODUCTION}

Calves are commonly weaned between 1 and 3 mo of age in many dairy systems, with the most common age being approximately $9 \mathrm{wk}$ in the United States (USDA, 2016). Weaning to dry feed requires that the calf has sufficiently developed gastrointestinal, hepatic, and peripheral enzyme systems to utilize changing sources of nutrients. If a calf is inadequately prepared for weaning, performance may suffer and predispose calves to reduced growth, poor efficiency, and increased susceptibility to disease (Roth et al., 2008, 2009).

The most important factor in promoting rumen development and preparation for weaning is consumption of dry feed containing fermentable carbohydrates that are fermented to propionate and butyrate in the rumen by resident rumen bacteria (Flatt et al., 1958; Sander et al., 1959). Production of VFA and microbial protein stimulate a series of adaptations in the rumen, gastrointestinal tract, hepatic tissues, and systemically that promote gluconeogenesis, production and release of BHB by rumen epithelium, and utilization of acetate by peripheral tissues (Howarth et al., 1968; Huber et al., 1961; Huber, 1969; Baldwin et al., 2004). 
Feeding milk or MR in excess of the traditional recommendations (approximately 10\% of BW as milk or reconstituted MR) has been shown to increase rate of gain and take advantage of improved feed efficiency (Diaz et al., 2001; Moallem et al., 2010; Davis-Rincker et al., 2011). High digestibility and metabolizability of liquid feeds compared with higher-fiber ingredients in calf starter (CS) may contribute to greater efficiency of BW gain.

Calves fed milk for ad libitum consumption or MR in amounts $>1 \mathrm{~kg}$ of powder per day gain more BW than calves fed conventional amounts (Jasper and Weary, 2002; Moallem et al., 2010). However, BW gain after weaning may be reduced due to inadequate preweaning starter intake and lack of rumen development. Weaning program also influences CS intake (Sweeney et al., 2010; de Passillé et al., 2011; Meale et al., 2015) and may contribute to lower digestion of nutrients postweaning. Some researchers suggest delayed weaning ( $>8$ wk of age) may reduce the reduction in BW gain due to weaning (de Passillé et al., 2011; Eckert et al., 2015; Meale et al., 2015).

Terré et al. (2007) fed Holstein bull calves (19 d of age at start of the trial) milk replacer (MR) at $4 \mathrm{~L} / \mathrm{d}$ with weaning at $35 \mathrm{~d}$ of the study, or an MR program that increased to $7 \mathrm{~L} / \mathrm{d}$ and then was reduced to weaning at $35 \mathrm{~d}$. Those authors reported that digestion of $\mathrm{NDF}$ was lower in calves fed $7 \mathrm{~L} / \mathrm{d}$ compared with $4 \mathrm{~L} / \mathrm{d}$ (20.3 vs. $34.7 \%$ ). Since disappearance of NDF is due primarily to ruminal fermentation, it is likely that reduced NDF digestion was due to inadequate or incomplete rumen fermentation in calves fed $7 \mathrm{~L} / \mathrm{d}$. Reduced NDF digestibility occurred despite a higher rumen $\mathrm{pH}$ (5.73 vs. 5.99). Others (Hill et al., 2010; Chapman et al., 2016) also reported lower postweaning nutrient digestion when calves were fed high amounts of MR preweaning.

Chapman et al. (2016) reported that digestion of nutrients, but particularly digestion of NDF and ADF, was reduced during the digestion period of d 52 to 58 of age when calves were fed MR up to $0.87 \mathrm{~kg} / \mathrm{d}$. Although digestion of all nutrients except starch was reduced significantly when calves were fed greater amounts of MR, digestion of NDF and ADF were reduced nearly $50 \%$ in calves fed large amounts of milk preweaning.

It is unclear whether amount of MR fed or the type of CS used might influence digestion of nutrients and subsequent growth. Therefore, the objective of our study was to evaluate digestion and performance of calves when fed 2 levels of MR and CS containing different levels of starch and fiber. Commercial high-starch CS $(\geq 40 \%)$ are typically manufactured as texturized feeds containing pellets and whole or processed grains, whereas commercial pelleted CS typically contain lower starch $(\leq 25 \%)$ and a greater proportion of higher NDF ingredients, such as soybean hulls and wheat middlings. We used this approach in manufacturing of feeds used in the current study.

\section{MATERIALS AND METHODS}

Holstein bull calves $(\mathrm{n}=48 ; 41.9 \mathrm{~kg}$ of $\mathrm{BW}, \mathrm{SE}=$ $0.7 ; 2$ to $3 \mathrm{~d}$ of age) were born at a single dairy farm and transported $3.5 \mathrm{~h}$ to the experimental site. Calves were weighed on the day after arrival, blood was collected by jugular venipuncture, and serum was separated by centrifugation at $3,000 \times g$ at $20^{\circ} \mathrm{C}$ for $15 \mathrm{~min}$ (VWR, Batavia, IL). Total serum protein concentration was estimated using an optical refractometer (ATAGO U.S.A. Inc., Bellevue, WA).

Calves were assigned randomly to receive either (DM basis) $0.66 \mathrm{~kg} / \mathrm{d}$ of $\mathrm{MR}$ powder $(25 \% \mathrm{CP}, 18 \%$ fat; Provimi, Brookville, $\mathrm{OH}$ ) to d 46 , then $0.33 \mathrm{~kg} / \mathrm{d}$ to weaning at d 49 (MRM), or $0.85 \mathrm{~kg} / \mathrm{d}$ to $5 \mathrm{~d}$, then $1.07 \mathrm{~kg} / \mathrm{d}$ to $\mathrm{d} 42$, then $0.53 \mathrm{~kg} / \mathrm{d}$ to weaning at $\mathrm{d}$ 49 (MRH). Milk replacers were reconstituted to 13 $(\mathrm{MRM})$ or $15 \%(\mathrm{MRH})$ solids with warm water $\left(45^{\circ} \mathrm{C}\right)$ and fed at approximately 0600 and $1600 \mathrm{~h}$ via buckets with nipples. Milk refusals were collected approximately $60 \mathrm{~min}$ after each feeding, weighed, and discarded. Calves were also assigned randomly to receive either a pelleted, low-starch (LSPEL) or texturized, highstarch (HSTEX) CS (Table 1). Starters LSPEL and HSTEX varied by ingredient (Table 1), contained similar amounts of protein and fat, but differed in amount of starch and fiber (Table 2). Starters and water were offered once daily at approximately $0800 \mathrm{~h}$ and were available for ad libitum consumption.

Table 1. Ingredient composition of starter feeds

\begin{tabular}{lcc}
\hline Ingredient, \% as-fed & $\begin{array}{c}\text { Low-starch } \\
\text { pelleted }\end{array}$ & $\begin{array}{c}\text { High-starch } \\
\text { textured }\end{array}$ \\
\hline Soybean hulls & 41.32 & - \\
Wheat middlings & 30.00 & 5.62 \\
Soybean meal, 48\% CP & 17.99 & 23.91 \\
Corn, whole & - & $37.00^{1}$ \\
Oats, whole & - & $25.00^{1}$ \\
Alfalfa meal & - & 0.70 \\
Maltodextrin & 2.50 & 0.70 \\
Molasses & 2.50 & $3.00^{1}$ \\
Fat & 2.00 & 0.26 \\
Calcium carbonate & 0.44 & 1.27 \\
Monocalcium phosphate & 0.33 & 0.78 \\
Magnesium oxide, 54\% Mg & - & 0.30 \\
Additives & -2.92 & 1.46 \\
\hline
\end{tabular}

${ }^{1}$ Not added to the pellet.

${ }^{2}$ Additives: Clarifly (Central Garden \& Pet Co., Schaumburg, IL) $0.67 \%$, salt, vitamin/mineral premix, Bovatec (Zoetis, Parsippany, NJ) premix, binder. 
Table 2. Chemical composition of experimental feeds

\begin{tabular}{lccc}
\hline Item, \% & $\begin{array}{c}\text { Milk } \\
\text { replacer }\end{array}$ & $\begin{array}{c}\text { Low-starch } \\
\text { pelleted }\end{array}$ & $\begin{array}{c}\text { High-starch } \\
\text { textured }\end{array}$ \\
\hline DM & 94.0 & 87.7 & 86.3 \\
DM basis & & 7.0 & 6.4 \\
Ash & 5.4 & 17.3 & 18.1 \\
CP & 25.1 & 21.3 & 4.6 \\
ADF & - & 36.9 & 13.3 \\
NDF & - & 5.9 & 7.9 \\
Sugar & - & 9.9 & 41.3 \\
Starch & 18.6 & 4.3 & 3.5 \\
Fat & & & \\
\hline
\end{tabular}

Calves were housed in a curtain-sided, naturally ventilated nursery with no added heat in $1.2-\times 2.4-\mathrm{m}$ individual pens bedded with straw for $56 \mathrm{~d}$. All animals were cared for as described in the Guide for the Care and Use of Agricultural Animals in Research and Teaching (FASS, 2010).

Calves were weighed initially and every $7 \mathrm{~d}$ thereafter. Hip widths of the calves were measured with a caliper and BCS was estimated initially and every 14 d. Calf BCS was based on a 1 to 5 system using 0.25 unit increments, with 1 being emaciated to 5 being obese (Wildman et al., 1982). Scores were based on changes around the vertical and transverse processes of the spine as palpated by 1 experienced technician. Starter intake offered and refused was measured daily. Feces were scored daily on a scale of $1=$ firm, normal, $2=$ less firm, normal, $3=$ thick, batter-like, $4=$ thin, batter-like, and $5=$ watery; modified from Kertz and Chester-Jones (2004). An abnormal fecal day was recorded when fecal score was $>2$.

On d 31 to 35 (wk 5), feces were collected from 5 calves randomly selected per treatment to estimate digestibility. During those $5 \mathrm{~d}$ and the preceding $7 \mathrm{~d}$, chromic oxide was added to the MR at each feeding as a digesta flow marker, as described by Hill et al. (2016). Calves were rectally palpated by hand to obtain a fecal sample. Fecal samples were systematically collected such that a total of 12 fecal samples were collected from each calf over $5 \mathrm{~d}$ to represent every $2 \mathrm{~h}$ in a 24 -h period. Starter was sampled daily over $5 \mathrm{~d}$, pooled, and MR powder was sampled. Pooled fecal samples were subsampled and analyzed for chromium ash relative to concentration in MR and feed intake over the 5-d period to estimate digestibility and fecal output.

Fecal grab samples were also collected from the same 5 calves per treatment on d 52 to 56 to estimate digestibility using acid insoluble ash as a fecal output marker. The trial was conducted between November 4 and December 30, 2015.

Composites of feeds and feces were analyzed for DM (oven method 930.15; AOAC International, 2000), ash (oven method 942.05; AOAC International, 2000), CP
(Kjeldahl method 988.05; AOAC International, 2000), ether extract (alkaline treatment with Roese-Gottlieb method 932.06 for MR, diethyl ether extraction method 2003.05 for starters and hay; AOAC International, 2000), NDF with ash by the procedure of Van Soest et al. (1991) without sodium sulfite or $\alpha$-amylase, ADF with ash (Robertson and Van Soest, 1981), starch ( $\alpha$-amylase method; Hall, 2009), sugar (colorimetric method; Dubois et al., 1956), Cr (Bouchard et al., 1973), and acid-insoluble ash (Van Keulen and Young, 1977).

Treatments were analyzed as a randomized complete block design with a $2 \times 2$ factorial arrangement of treatments with calf as experimental unit and using the Mixed procedure of SAS (version 8, SAS Institute Inc.). Repeated measures were used when variables were measured over time. An auto-regressive type 1 covariance matrix was employed as determined using Akaike's information criterion (AIC) for most variables. Unstructured covariance reduced AIC for digestibility measurements. Contrast statements were constructed to separate differences in the level of MR intake, starter type, and interaction; differences were declared at $P \leq 0.05$ and tendencies at $P \leq 0.10$. Least squares means were separated using the PDIFF option in the Mixed procedure when the interaction term was significant $(P<0.05)$. Weekly fecal scores, number of abnormal fecal days, and number of days animals were treated were analyzed using the GLIMMIX procedure of SAS to model non-normal distributions.

We modeled effects of dry feed intake and treatment on total-tract digestion of starch and NDF using Proc Mixed to model effects of nutrient intake on total-tract nutrient digestion at 5 and 8 wk of age. Intakes of starch and NDF were calculated during the digestibility measurement period, as were cumulative starch and NDF intakes from birth to the end of the digestibility measurement period. Nutrient digestion was then evaluated as dependent variable using Proc Mixed procedure of SAS with treatment and nutrient intake, cumulative nutrient intake, or the natural logarithm of each included in the model. Calf was included in the model as a random variable. The Bayesian information criterion (BIC) and AIC statistics were used to indicate optimal independent variables in the model.

\section{RESULTS}

Average temperature was $6^{\circ} \mathrm{C}$ with a range from -7 to $25^{\circ} \mathrm{C}$. Average relative humidity was $84 \%$ with a range from 31 to $100 \%$. Initial measurements of BW and BCS did not differ by treatment, though initial hip widths were greater for calves fed LSPEL (Table 3). Serum total protein differed by CS and MR and calves 
fed MRH + HSTEX had lower total protein than calves fed MRM + HSTEX. Calves fed MRM consumed all MR offered whereas calves fed MRH consumed $97 \%$ of MR offered. Milk replacer DMI averaged $0.54 \mathrm{~kg} / \mathrm{d}$ for MRM and $0.83 \mathrm{~kg} / \mathrm{d}$ for MRH for d 0 to 56 . Starter intake was lower when calves were fed $\mathrm{MRH}$ versus MRM (0.38 vs. $0.75 \mathrm{~kg} / \mathrm{d})$. Final BW and ADG were greater when calves were fed MRH versus MRM (Table $3)$. Medical days and days with abnormal fecal scores were unaffected by treatment. Medical days were primarily treatments for respiratory disease. Interaction of $\mathrm{CS} \times \mathrm{MR}$ was significant for final hip width and feed efficiency and a trend $(P<0.09)$ was significant for ADG. Calves fed MRH + LSPEL had greater final hip width compared with those fed MRM + LSPEL and MRH + HSTEX, with calves fed MRM + HSTEX being intermediate. Feed efficiency was greater in calves fed MRH + LSPEL compared with calves fed MRM + LSPEL, with calves fed HSTEX being intermediate. Calves fed MRH also tended $(P<0.06)$ to have higher final BCS than calves fed MRM, though BCS change did not differ among treatments. Other measures of growth or intake did not vary by CS composition.

Body weights were affected by treatment, week, and a week $\times$ treatment interaction. Calves fed MRM had lower BW than calves fed MRH after wk 1 (Figure 1).
Differences among treatments were less at wk 7 and 8 , as calves fed MRM increased CS intake (Figure 2) and BW (Figure 1) in response to weaning. We found no effect of CS composition on BW, though calves fed MRH + LSPEL had numerically greater BW compared with calves fed MRH + HSTEX from wk 4. Starter intake was higher in calves fed MRM versus MRH from wk 4 (Figure 2); differences in intake were greatest during wk 7 when MR was reduced to weaning at d 49. We observed was no significant effect of CS composition on CS intake.

Digestibilities of nutrients at 5 and 8 wk (Table 4 ) were affected by treatment, week, or week $\times$ treatment interactions. Therefore, nutrient digestibility data are presented by week and treatment.

Digestibilities of DM and $\mathrm{OM}$ at 5 wk were affected by $\mathrm{CS}$, level of MR, and a CS $\times$ MR interaction. Digestibilities of $\mathrm{DM}$ and $\mathrm{OM}$ at 5 wk were particularly low in calves fed MRM + LSPEL $(\mathrm{MR} \times \mathrm{CS}$ interaction was significant at $P<0.02$ ). By wk $8, \mathrm{DM}$ and $\mathrm{OM}$ increased in calves fed MRM + LSPEL but decreased in calves in other treatment groups. Also, digestion of $\mathrm{DM}$ and $\mathrm{OM}$ at 8 wk were lower in calves fed LSPEL versus HSTEX and MRH versus MRM. Both DM and OM digestion at 8 wk tended to be lower in calves fed $\mathrm{MRH}+$ LSPEL.

Table 3. Performance of calves fed milk replacers at two rates and pelleted or texturized calf starters

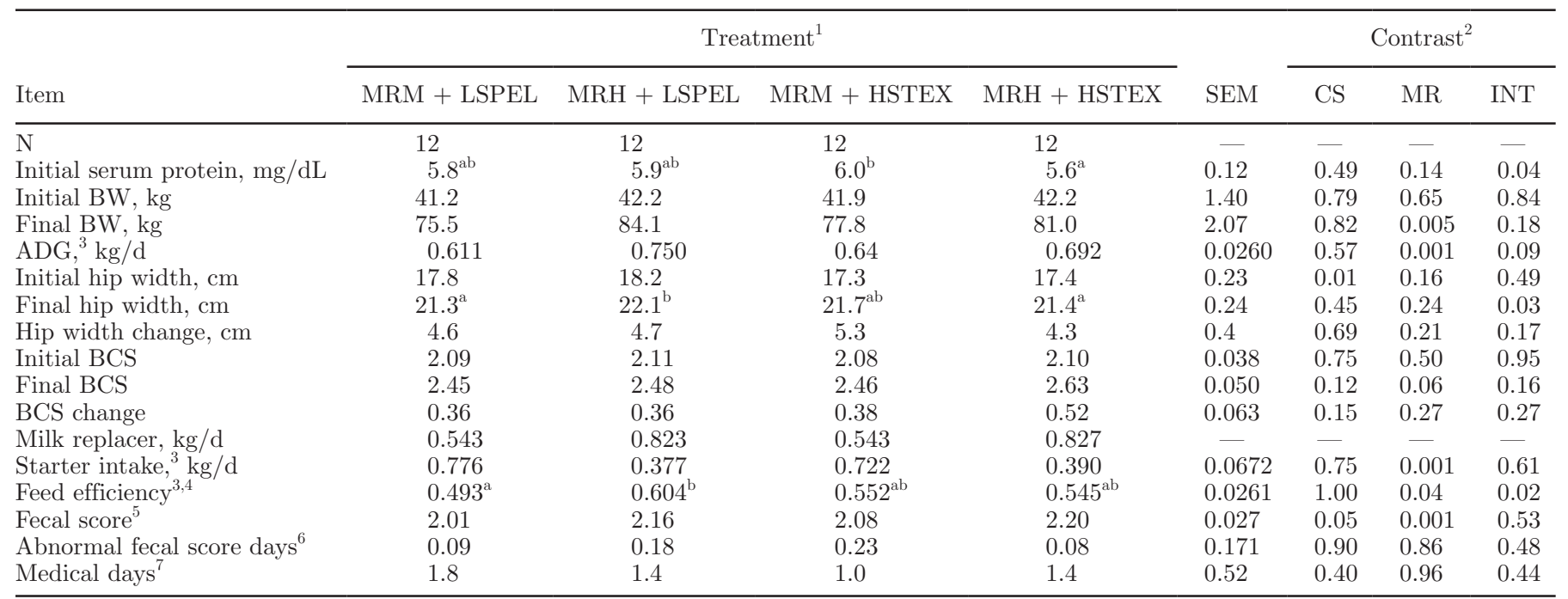

\footnotetext{
${ }_{\mathrm{a}, \mathrm{b}}$ Means in the same row with different superscripts differ, $P<0.05$.

${ }^{1}$ Milk replacer was fed at $\mathrm{MRM}=0.66 \mathrm{~kg} / \mathrm{d}$ for $46 \mathrm{~d}$, then $0.33 \mathrm{~kg} / \mathrm{d}$ for $3 \mathrm{~d}$ or $\mathrm{MRH}=0.85 \mathrm{~kg} / \mathrm{d}$ for $5 \mathrm{~d}$, then $1.07 \mathrm{~kg} / \mathrm{d}$ for $37 \mathrm{~d}$, then 0.53 $\mathrm{kg} / \mathrm{d}$ for $7 \mathrm{~d}$ (DM basis). Calf starters were low starch, pelleted (LSPEL) or high starch, texturized (HSTEX).

${ }^{2}$ Probability of a significant effect of starter $(\mathrm{CS})$, intake of MR $(\mathrm{MR})$, or interaction of $\mathrm{CS} \times \mathrm{MR}(\mathrm{INT})$.

${ }^{3}$ Significant effects of week $(P<0.001)$ and week $\times$ treatment $(P<0.001)$.

${ }^{4} \mathrm{BW}$ gain divided by milk replacer plus starter intake.

${ }^{5}$ Feces was scored on a 5 -point system with $1=$ thick, $2=$ less thick, $3=$ abnormal like batter, $4=$ abnormal, watery with color, $5=$ abnormal, watery with little color. Significant effect of week $(P<0.001)$.

${ }^{6}$ Total number of days calves had fecal score $>2$.

${ }^{7}$ Total number of days calves were treated with veterinary medications.
} 
Digestion of ADF at 5 wk was affected by CS, MR, and a $\mathrm{CS} \times \mathrm{MR}$ interaction. Digestion of ADF was highest $(62.3 \%)$ when calves were fed MRM + HSTEX; $\mathrm{ADF}$ digestion was $<25 \%$ in other groups. By $8 \mathrm{wk}$, digestion of ADF increased in calves fed LSPEL, but decreased when calves were fed HSTEX. Digestion of $\mathrm{ADF}$ did not differ from zero in calves fed $\mathrm{MRH}+$ HSTEX at 8 wk. Differences due to CS and MR were both significant for ADF digestion at $8 \mathrm{wk}$.

Digestion of NDF at 5 wk was lower in calves fed MRH (19.4\%) compared with MRM (41.7\%). We found no significant effect of CS on NDF digestion at 5 wk. At $8 \mathrm{wk}$, digestion of NDF was lower when calves were fed $\mathrm{MRH}$ versus MRM (46.5 vs. $59.3 \%$ ) and when calves were fed HSTEX versus LSPEL (40.5 vs. $65.3 \%$ ).

Starch digestion at 5 wk was lower in calves fed LSPEL versus HSTEX (51.0 vs. $73.5 \%$ ) and in calves fed $\mathrm{MRH}$ versus MRM (52.5 vs. $72.1 \%$ ). At $8 \mathrm{wk}$, starch digestion was higher in calves fed LSPEL (98.3\%) versus HSTEX (96.1\%). Starch digestion at 8 wk tended $(P<0.07)$ to be lowest in calves fed MRM + HSTEX (95.0\%).

Digestion of CP averaged $70.7 \%$ at 5 wk at was lower when calves were fed MRM versus MRH (66.5 vs. $75.0 \%)$ and tended $(P<0.11)$ to be lower when calves were fed LSPEL versus HSTEX (67.3 vs. $74.2 \%$ ). The $\mathrm{CS} \times \mathrm{MR}$ interaction was not significant. At $8 \mathrm{wk}, \mathrm{CP}$ digestion tended to be lower in calves fed MRH versus MRM.

Fat digestion at 5 wk was lower in calves fed MRM versus MRH $(86.7$ vs. $92.2 \%)$ and tended $(P<0.11)$ to be lower in calves fed LSPEL versus HSTEX (87.5 vs. $91.5 \%)$. At 8 wk, fat digestion was lower in calves fed HSTEX (88.2\%) versus LSPEL (91.3\%).

Total-tract digestion of starch (Figure 3) and NDF (Figure 4) measured throughout the study were best described (lowest BIC and AIC) by the natural logarithm of cumulative starch and NDF intakes, respectively. Including average daily intake of DM, starch, or NDF resulted in greater BIC and AIC statistics compared with cumulative nutrient intake. Change in total-tract starch digestion was also affected $(P<0.05)$ by starter program, whereas NDF digestion was affected $(P<$ $0.05)$ by MR program.

\section{DISCUSSION}

Calves fed larger amounts of MR generally ate less CS and grew more rapidly than calves fed a moderate amount of MR. Calves fed MRH also had higher fecal scores, which is consistent with other published research (Quigley et al., 2006; Osorio et al., 2012). Others, however, have reported no effect of MR feeding level on fecal scores or treatment frequency (Jasper and Weary,

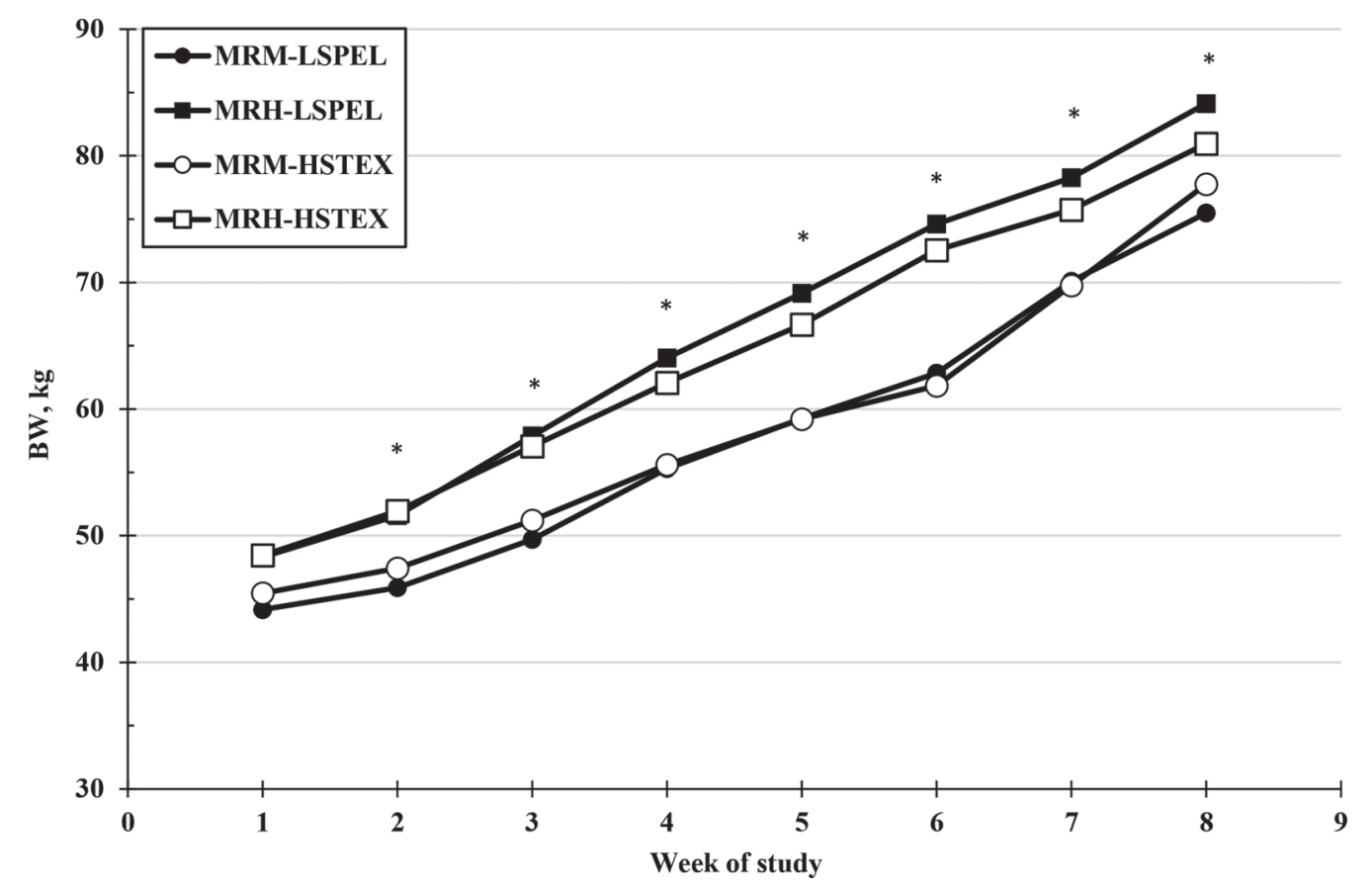

Figure 1. Least squares means of BW in calves fed moderate (MRM) or high (MRH) milk replacer and low-starch, pelleted (LSPEL) or high-starch, texturized (HSTEX) calf starter (SEM = 1.82). Milk replacer was fed at MRM $=0.66 \mathrm{~kg} / \mathrm{d}$ for $46 \mathrm{~d}$, then $0.33 \mathrm{~kg} / \mathrm{d}$ for $3 \mathrm{~d}$ or $\mathrm{MRH}$ $=0.85 \mathrm{~kg} / \mathrm{d}$ for $5 \mathrm{~d}$, then $1.07 \mathrm{~kg} / \mathrm{d}$ for $37 \mathrm{~d}$, then $0.53 \mathrm{~kg} / \mathrm{d}$ for $7 \mathrm{~d}$ (DM basis). For each week, an asterisk $(*)$ denotes significant differences $(P<0.05)$ between MRM and MRH. 
2002; Ballou et al., 2013). Feed efficiency was affected by a week $\times$ treatment interaction, so we evaluated feed efficiency during wk 1 to 6 (preweaning) and 7 to 8 (periweaning). During wk 1 to 6 , least squares means of feed efficiency were $0.505,0.644,0.500$, and 0.603 $(\mathrm{SEM}=0.030)$ for MRM + LSPEL, MRH + LSPEL, MRM + HSTEX, and MRH + HSTEX, respectively, and were greater $(P<0.001)$ in calves fed MRH versus MRM. We found no effect of CS type, nor was the $\mathrm{CS} \times \mathrm{MR}$ interaction significant. During wk 7 to 8 , least squares means of feed efficiency were $0.457,0.483$, 0.709 , and 0.371 (SEM $=0.053)$, respectively, and were affected by MR feeding $(P<0.003)$ and a $\mathrm{CS} \times \mathrm{MR}$ interaction $(P<0.001)$. Calves fed MRM + HSTEX were more efficient in utilizing nutrients during the last 2 wk of the study. Increased MR feeding has been reported to increase feed efficiency (Ballou et al., 2015; Yunta et al., 2015), though others have reported no effect of a moderate versus high rate of MR feeding on feed efficiency (Bach et al., 2013; Chapman et al., 2016; Hill et al., 2016; Byrne et al., 2017; Quigley et al., 2017). Changes in hip width and BCS were unaf- fected by treatment (Table 3), which is similar to other reports comparing MR feeding rates (Hill et al., 2010, 2016; Chapman et al., 2016).

Weekly changes in calf BW (Figure 1) and CS intake (Figure 2) reflected intake of MR. Calves fed MRH consumed $<300 \mathrm{~g} / \mathrm{d}$ of DM from CS until 6 wk of the study. Reduced preweaning CS intake in calves fed $>800 \mathrm{~g} / \mathrm{d}$ of DM from milk or MR has been reported (Jasper and Weary, 2002; Bach et al., 2013; Chapman et al., 2016). Intake of DM from CS increased to approximately 800 $\mathrm{g} / \mathrm{d}$ by 6 wk in calves fed MRM. Intake of CS increased more than 2 fold (MRM) and approximately 4 fold $(\mathrm{MRH})$ during wk 7 , when MR offered was reduced in preparation for weaning. Intake of CS increased rapidly in calves fed MRM from 6 to $7 \mathrm{wk}$ but did not change from 7 to $8 \mathrm{wk}$ (Figure 4), independent of CS type. Intake of $\mathrm{CS}$ in calves fed $\mathrm{MRH}$ doubled again from 7 to $8 \mathrm{wk}$, independent of CS type.

Intake of ME from MR declined during wk 7 as MR allotment was reduced to weaning. The $\mathrm{MR}$ in our study provided 4.80 Mcal of $\mathrm{ME} / \mathrm{kg}$ of $\mathrm{DM}$ (NRC, 2001); calves fed MRM consumed 3.17 Mcal of ME/d

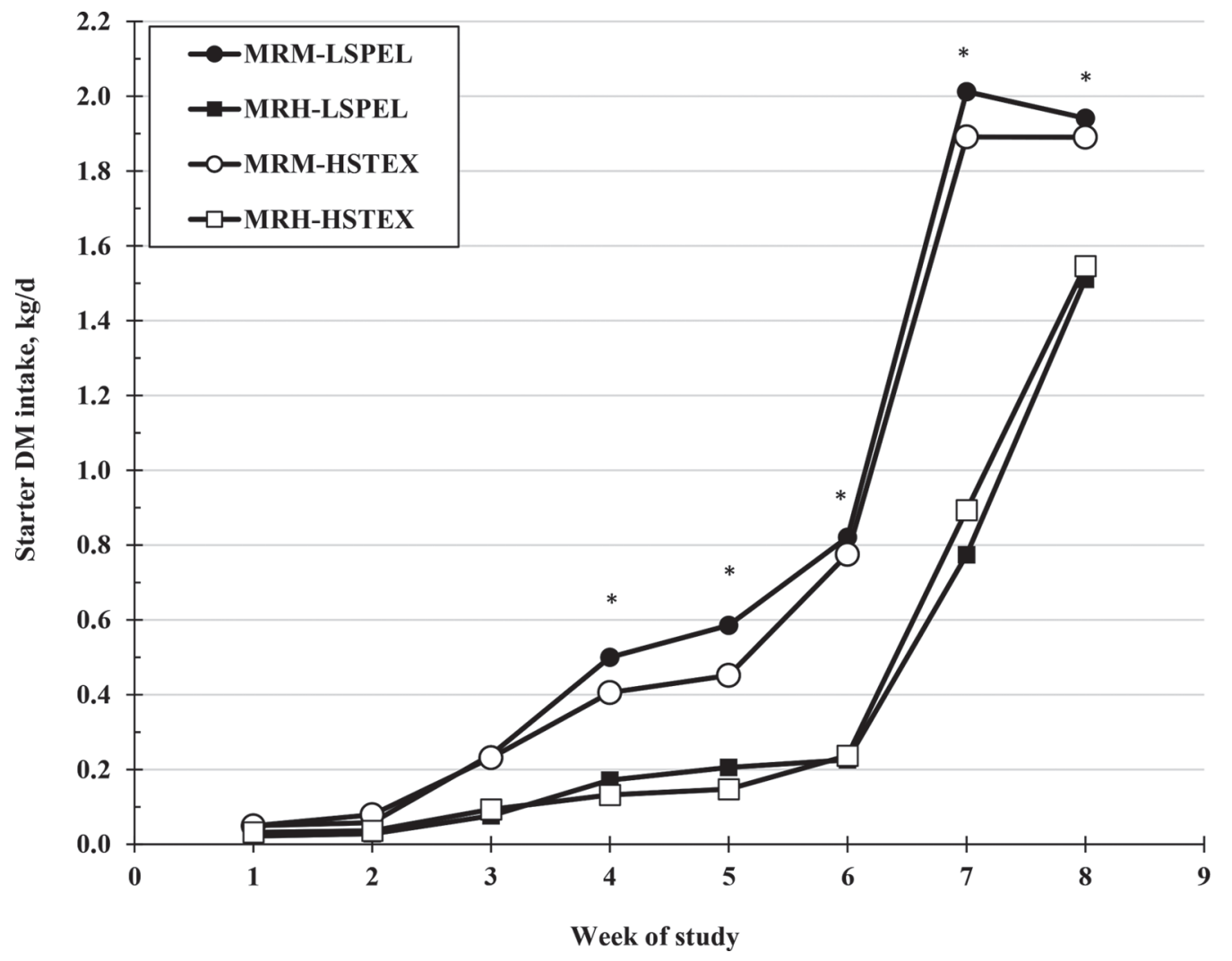

Figure 2. Least squares means of calf starter DMI in calves fed moderate (MRM) or high (MRH) amounts of milk replacer and low-starch, pelleted (LSPEL) or high-starch, texturized (HSTEX) calf starter (SEM $=0.085)$. Milk replacer was fed at $\mathrm{MRM}=0.66 \mathrm{~kg} / \mathrm{d}$ for $46 \mathrm{~d}$, then 0.33 $\mathrm{kg} / \mathrm{d}$ for $3 \mathrm{~d}$ or $\mathrm{MRH}=0.85 \mathrm{~kg} / \mathrm{d}$ for $5 \mathrm{~d}$, then $1.07 \mathrm{~kg} / \mathrm{d}$ for $37 \mathrm{~d}$, then $0.53 \mathrm{~kg} / \mathrm{d}$ for $7 \mathrm{~d}(\mathrm{DM}$ basis). For each week, an asterisk $(*)$ denotes significant differences $(P<0.05)$ between MRM and MRH. 


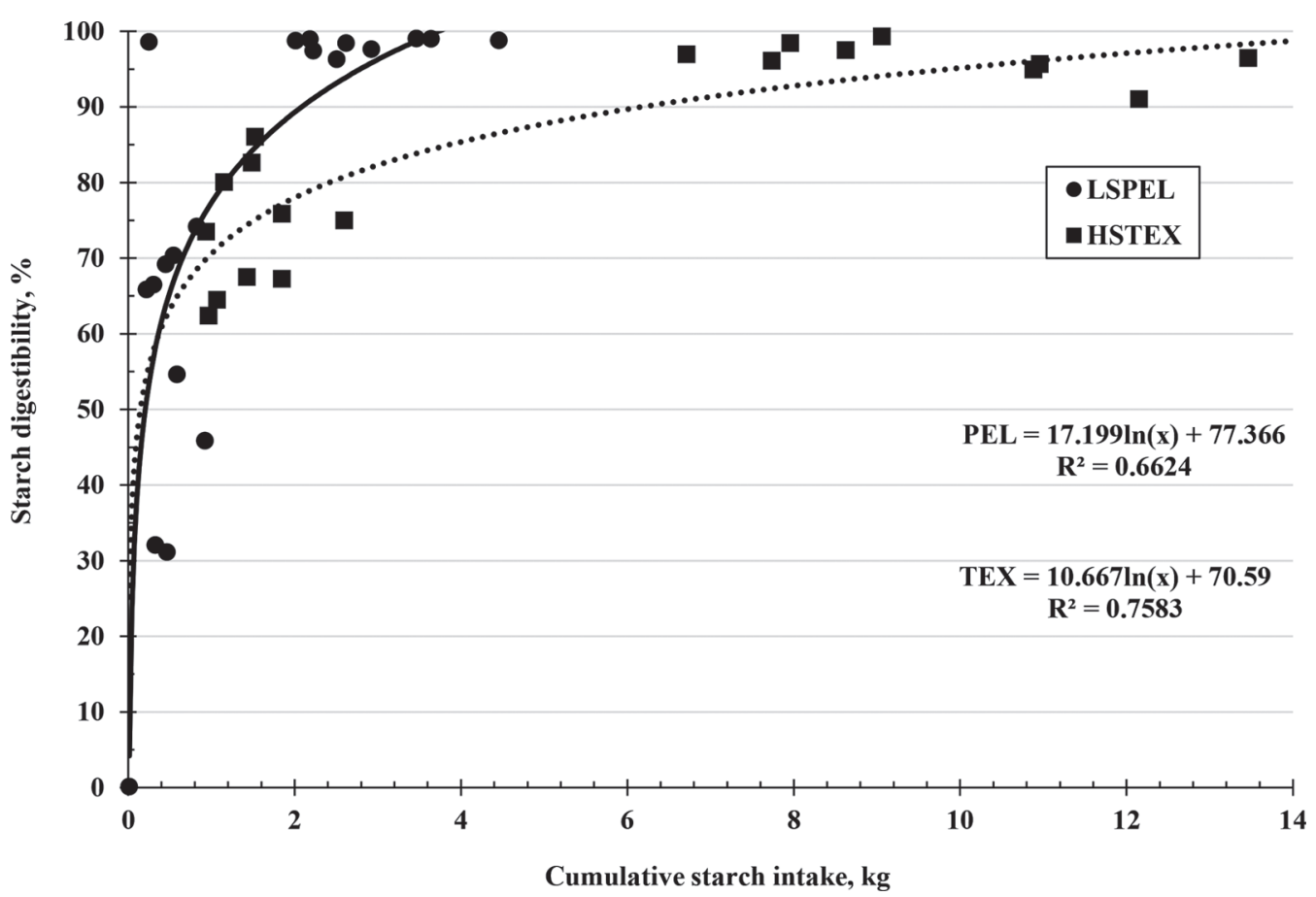

Figure 3. Relationship between total-tract starch digestion and cumulative starch intake in calves fed low-starch, pelleted (LSPEL) or highstarch, texturized (HSTEX) calf starters.

Table 4. Least squares means of BW, intake of milk replacer (MR) and calf starter (CS) DM and digestion of selected nutrients by calves fed $\mathrm{MR}$ at 2 rates with starters with low and high starch concentrations during wk 5 and 8

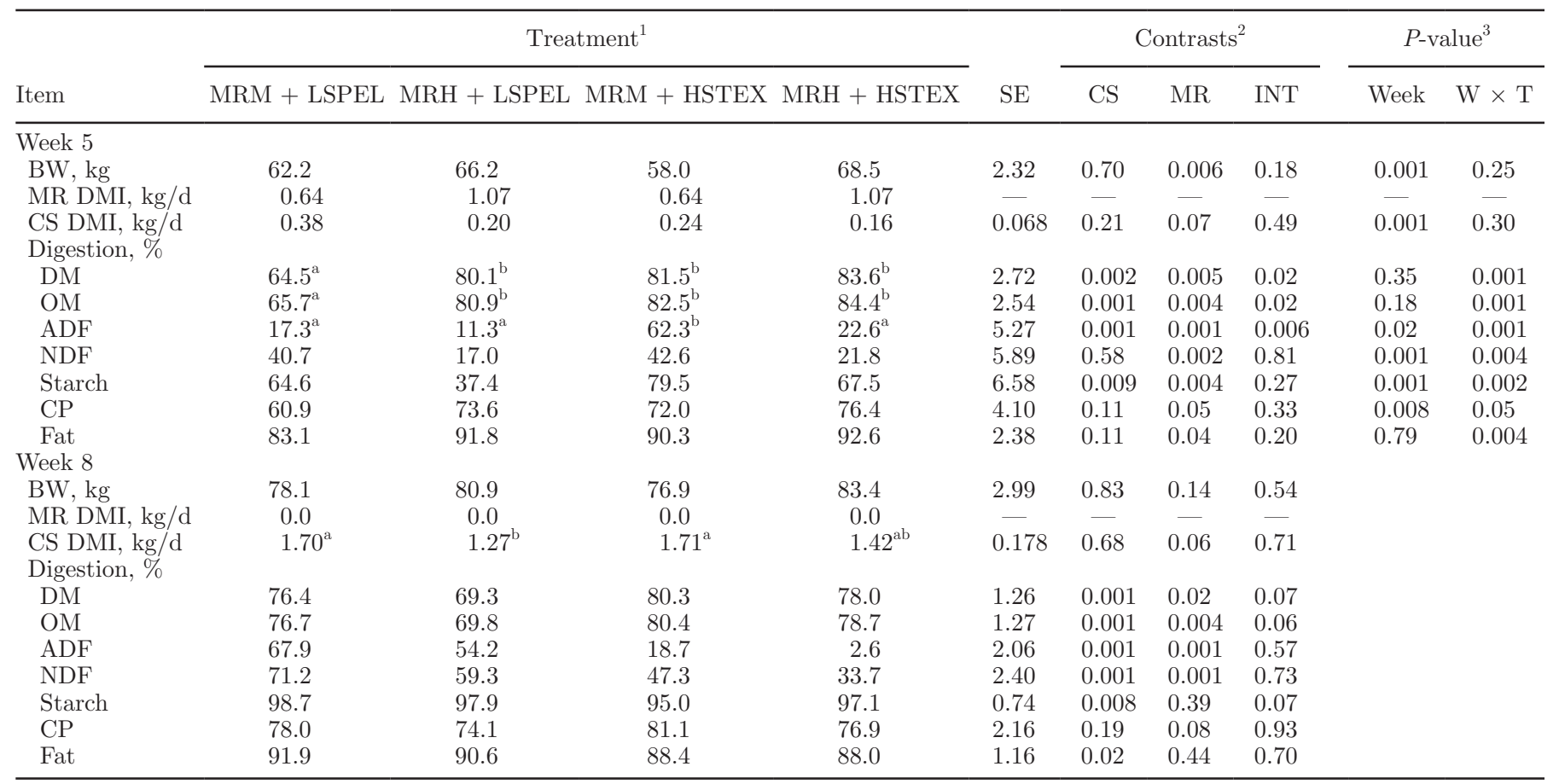

${ }^{\mathrm{a} c}$ Means in the same row with different superscripts differ, $P<0.05$.

${ }^{1}$ Milk replacer was fed at MRM $=0.66 \mathrm{~kg} / \mathrm{d}$ for $46 \mathrm{~d}$, then $0.33 \mathrm{~kg} / \mathrm{d}$ for $3 \mathrm{~d}$ or $\mathrm{MRH}=0.85 \mathrm{~kg} / \mathrm{d}$ for $5 \mathrm{~d}$, then $1.07 \mathrm{~kg} / \mathrm{d}$ for $37 \mathrm{~d}$, then 0.53 $\mathrm{kg} / \mathrm{d}$ for $7 \mathrm{~d}$ (DM basis). Calf starters were low starch, pelleted (LSPEL) or high starch, texturized (HSTEX).

${ }^{2}$ Probability of a significant effect of starter $(\mathrm{CS})$, intake of MR (MR), or interaction of CS $\times$ MR (INT) within week.

${ }^{3}$ Probability of a significant week and week $\times$ treatment $(\mathrm{W} \times \mathrm{T})$ interaction. 


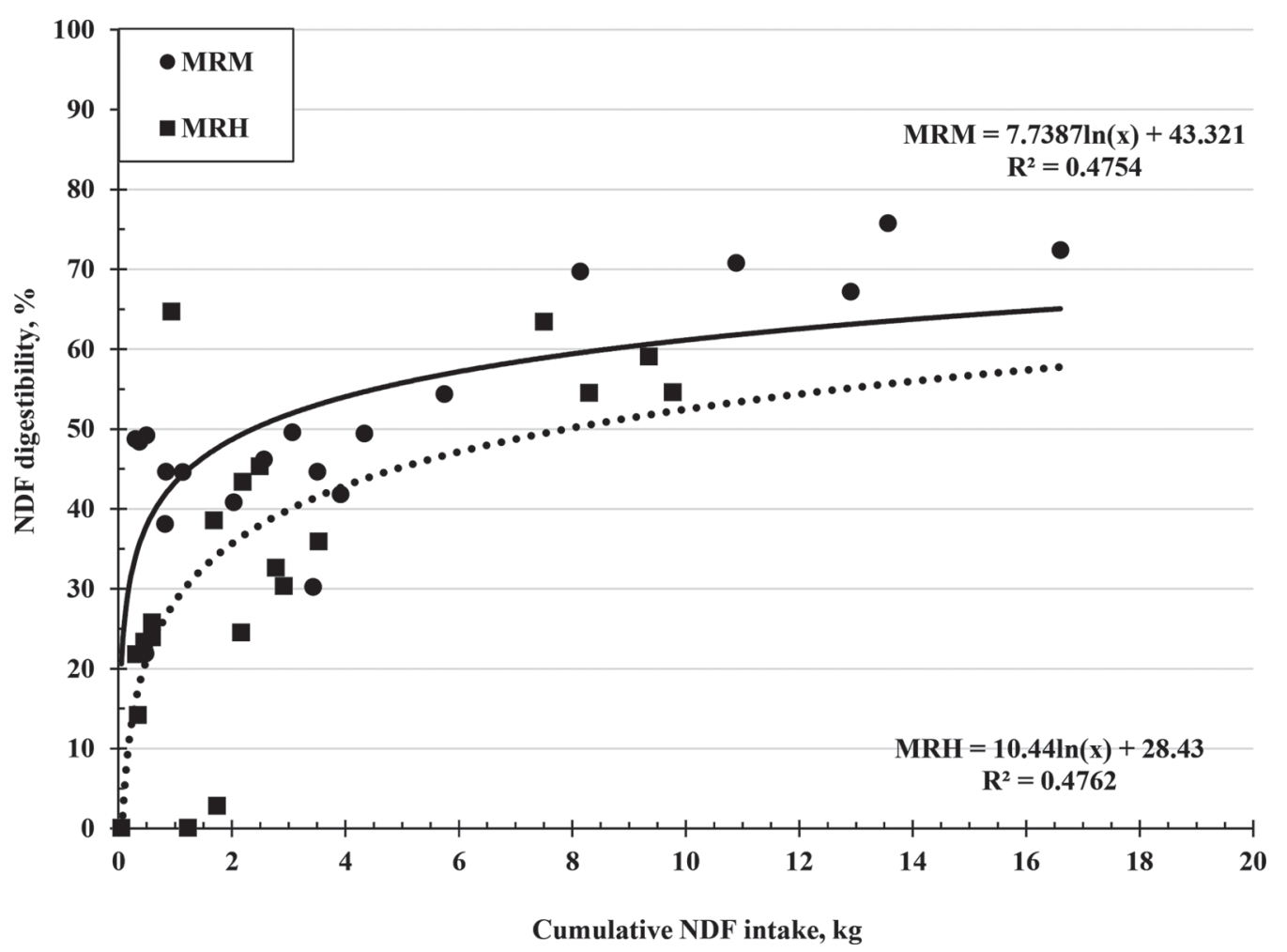

Figure 4. Total-tract NDF digestion and cumulative NDF intake in calves at moderate (MRM) or high (MRH) rates of MR. Milk replacer was fed at $M R M=0.66 \mathrm{~kg} / \mathrm{d}$ for $46 \mathrm{~d}$, then $0.33 \mathrm{~kg} / \mathrm{d}$ for $3 \mathrm{~d}$ or $\mathrm{MRH}=0.85 \mathrm{~kg} / \mathrm{d}$ for $5 \mathrm{~d}$, then $1.07 \mathrm{~kg} / \mathrm{d}$ for $37 \mathrm{~d}$, then $0.53 \mathrm{~kg} / \mathrm{d}$ for $7 \mathrm{~d}$ (DM basis).

from d 1 to 46 and $1.58 \mathrm{Mcal}$ of ME/d from d 47 to 49. Calves fed MRH consumed 4.08, 5.13, and 2.54 Mcal of ME/d during d 1 to 5,6 to 42 , and 43 to 49 .

As in other studies (Bach et al., 2013; Yunta et al., 2015; Chapman et al., 2016), calves fed more MR gained more BW to weaning; however, in the last $2 \mathrm{wk}$ of our study, when the amount of MR offered was reduced, intake of CS increased more rapidly in calves fed MRM with a concomitant increase in BW. However, ending BW remained greater in calves fed $\mathrm{MRH}$ versus MRM $(82.6$ vs. $76.6 \mathrm{~kg})$. A common industry recommendation is for calves to double birth BW by $56 \mathrm{~d}$ of age (Bjorklund et al., 2013). In our study, 12 of 48 calves doubled the BW measured at the start of the trial (2-3 $\mathrm{d}$ of age). One, 6,1 , and 4 calves doubled BW by $56 \mathrm{~d}$ in treatments MRM + LSPEL, MRH +LSPEL, MRM + HSTEX, and MRH + HSTEX, respectively.

Weaning management (i.e., length of time calves are fed a reduced amount of liquid fed or extent to which liquid is reduced) may influence starter intake, particularly when large amounts of liquid are fed (Sweeney et al., 2010; de Passillé et al., 2011; Rosenberger et al., 2017). For example, Sweeney et al. (2010) reported that calves fed up to $12 \mathrm{~L} / \mathrm{d}$ of whole milk via automated feeders and weaned over $10 \mathrm{~d}$ (beginning on d 31, milk offered reduced by $10 \% / \mathrm{d}$ ) had best overall BW gain compared with calves weaned abruptly at $41 \mathrm{~d}$ or gradually over 3 or $22 \mathrm{~d}$ to weaning on d 41 . de Passillé (2011) also suggested that delaying weaning to 12 or 13 wk in calves fed large amounts of milk via automated feeders may reduce the negative effect of weaning on energy intake and growth.

Weaning management is usually less complex when calves are hand-fed a limited amount of MR once or twice daily. Typically, liquid allotment is reduced in 1 or 2 steps beginning at 2 or 1 wk preweaning. In our study, amount of MR offered was reduced by $50 \%$ for 3 (MRM) or 7 (MRH) d before weaning at d 49. The rapid increase in CS intake that occurred with reduction in liquid allotted during wk 7 was not preceded by substantial CS intake in calves fed MRH. Cumulative CS intake through 6 wk were 15.7, 5.1, 13.9, and 4.7 $\mathrm{kg}$ of DM for MRM + LSPEL, MRH + LSPEL, MRM + HSTEX, and MRH + HSTEX, respectively. Rumen development depends on availability of fermentable substrate in the rumen (particularly carbohydrates); therefore, intake of a sufficient amount of CS before weaning transition is necessary. We hypothesized that sufficient CS intake was required at least 2 to $3 \mathrm{wk}$ before weaning to allow changes in rumen microflora 
and papillary growth necessary before weaning. In our study, low intake of CS $(\leq 5 \mathrm{~kg}$ of cumulative CS DMI) from wk 1 to 6 in calves fed MRH may have contributed to lower ADG in calves fed MRH during wk 7 to 8 . Least squares means of ADG during wk 7 to 8 were $0.903,0.679,1.136$, and $0.600(\mathrm{SEM}=$ $0.0525)$ for MRM + LSPEL, MRH + LSPEL, MRM + HSTEX, and MRH + HSTEX, respectively, and were lower in calves fed MRH $(P<0.001)$. Reduced ADG in calves fed MRH may also be a response to lower nutrient digestibility. Least squares means of intake of daily digestible $\mathrm{OM}$ during d 52 to 56 (3-7 d postweaning) were $1.31,0.88,1.37$, and $1.12 \mathrm{~kg} / \mathrm{d}(\mathrm{SEM}=$ 0.10) for MRM + LSPEL, MRH + LSPEL, MRM + HSTEX, and MRH + HSTEX, respectively. Digestible OM intake was $25 \%$ lower $(P<0.02)$ when calves were fed MRH versus MRM.

Digestibility of nutrients may be affected by ration form (Porter et al., 2007), though others have reported no effect of pelleted versus texturized CS on digestion or growth when similar ingredients were included in each form (Coverdale et al., 2004; Bach et al., 2007; Nejad et al., 2012). We recognized that form of CS (pelleted or textured) and carbohydrate content of CS were completely confounded in the current study. Therefore, it was not possible to determine unequivocally whether differences due to CS formulation in our study were related specifically to form, nutrient content, or both.

Studies documenting effect of CS form on nutrient digestion are conflicting. For example, Nejad et al. (2012) fed CS containing the same ingredients in ground, pelleted, or texturized forms. Apparent total-tract digestibilities of DM, OM, and CP in ground starter were lower than pelleted or texturized CS when digestion was measured 1 wk postweaning. However, we found no difference in digestion of nutrients when calves were fed either pelleted or texturized CS. Conversely, Porter et al. (2007) reported greater nutrient (DM, fat, ADF, $\mathrm{NDF}$ ) digestion (measured at 7-8 wk) in calves weaned at approximately $28 \mathrm{~d}$ of age and fed texturized CS. Differences in age postweaning, ingredients in CS, ingredient processing, and nutrient intake could influence reported nutrient digestibilities.

Total-tract nutrient digestibility during the first 8 wk of life was highly influenced by source of nutrients. Effects of week and week $\times$ treatment interaction were significant $(P<0.05)$ for all nutrients measured. Differences in nutrient intake, ontogeny of the gastrointestinal tract, and digestibility of MR versus CS undoubtedly contributed to differences in digestion between 5 and $8 \mathrm{wk}$.

At $5 \mathrm{wk}$, calves consumed a portion of their nutrients from both CS and MR. Calves consumed 37, 16, 27, and $13 \%$ of total DM from CS in MRM + LSPEL, MRH +
LSPEL, MRM + HSTEX, and MRH + HSTEX treatments, respectively, in the subset of 5 calves/treatment used to measure digestibility. Differences in CS intake at $5 \mathrm{wk}$ for calves in the digestibility portion of the trial tended $(P<0.07)$ to be greater in calves fed MRM (0.31 vs. $0.18 \mathrm{~kg} / \mathrm{d}$, respectively, for MRM vs. MRH). Digestion of DM, OM, CP, and fat were lower in calves fed MRM during wk 5 and could be related to the proportion of total DM as CS. Conversely, digestion of $\mathrm{ADF}, \mathrm{NDF}$, and starch were greater in calves fed MRM at $5 \mathrm{wk}$, suggesting greater development of ruminal, pancreatic, or large intestinal mechanisms for fiber and starch disappearance.

Form of CS also affected nutrient digestion at $5 \mathrm{wk}$. Calves fed LSPEL had lower digestion of DM, OM, ADF, starch, and a tendency $(P<0.11)$ for lower digestion of $\mathrm{CP}$ and fat (Table 4). This is particularly true of calves fed MRM + LSPEL, which had lowest digestibility of DM and OM. Overall, calves fed MRM + LSPEL had numerically greatest CS intake, and ingredients in LSPEL (e.g., soybean hulls, wheat middlings) were less digestible than ingredients in HSTEX (corn, oats).

Generally, digestibilities of DM, protein, and fat from milk-based ingredients in MR are greater than those of dry feed; thus, it is likely that differences in digestion of nutrients at 5 wk reflected the different sources of nutrients ingested. Calves fed MRM at 5 wk consumed the greatest proportion of their DM from CS, so lower digestibility of $\mathrm{DM}$ and $\mathrm{OM}$ and higher digestion of ADF, NDF, and starch may have been related to greater intake of these nutrients from CS.

Nutrient digestion at 8 wk reflected only CS intake, as calves were weaned at $49 \mathrm{~d}$. Reduced digestion of $\mathrm{DM}, \mathrm{OM}, \mathrm{ADF}$, and NDF when calves were fed MRH versus MRM may be related to lower CS intake before weaning (Table 3) and lack of rumen development.

Digestion of DM and OM were greater in calves fed HSTEX versus LSPEL; however digestion of starch, fat and fiber were lower in calves fed HSTEX. It is important to consider that fiber intake varied by CS treatment. Intakes of $\mathrm{ADF}$ during the wk 8 digestion measurement period were $0.36,0.27,0.08$, and 0.07 $\mathrm{kg} / \mathrm{d}$ for calves fed MRM + LSPEL, MRH + LSPEL, MRM + HSTEX, and MRH + HSTEX, respectively; similarly, intakes of NDF were $0.63,0.47,0.23$, and 0.19 $\mathrm{kg} / \mathrm{d}$, respectively. Although fiber digestion was much lower in calves fed HSTEX, the total amount of fiber in DM was quite small and differences in ADF digestion at 8 wk could be due to low ADF in HSTEX, resulting in high variability with low values. In the pelleted calf starters, lower ADF and NDF digestibility compared with starch resulted in lower overall DM and OM digestibility. Digestion of starch at 8 wk differed 
by treatment (Table 4); however, biological significance was likely limited.

Digestion of DM, OM, CP, and fat in our study at 5 wk compare favorably with data of Chapman et al. (2017), who measured total-tract digestion of nutrients from 35 to $42 \mathrm{~d}$ of age in calves fed varying amounts of MR to weaning at $49 \mathrm{~d}$ and a texturized, $39 \%$ starch CS. Mean DM, OM, and CP digestion in calves fed 0.67 or $0.87 \mathrm{~kg}$ of $\mathrm{MR} / \mathrm{d}$ were unaffected by treatment and averaged $83.8,84.4$, and $79.2 \%$, respectively (Chapman et al., 2017). Total-tract digestion of ADF, NDF, and starch were much lower in our calves and may be related to lower CS intake by our calves compared with those of Chapman et al. (2017). Mean ADF, NDF, and starch digestion in calves of Chapman et al. (2017) were unaffected by feeding 0.67 or $0.87 \mathrm{~kg}$ of $\mathrm{MR} / \mathrm{d}$ and averaged 59.7, 68.7, and $99.4 \%$, respectively, which was higher than the $42.5,32.2$, and $73.5 \%$ in calves fed HSTEX at 5 wk (Table 4). Calves in the study of Chapman et al. (2017) consumed from 0.4 to $1.1 \mathrm{~kg} / \mathrm{d}$ of CS during the digestion period (35-42 d), whereas our calves consumed 0.2 to $0.4 \mathrm{~kg} / \mathrm{d}$. Our data at $5 \mathrm{wk}$ also compare favorably to nutrient digestibilities measured from d 40 to 44 in calves fed 0.66 or up to $1.3 \mathrm{~kg} / \mathrm{d}$ of MR to weaning at $49 \mathrm{~d}$ of age (Hill et al., 2016).

Nutrient digestion at 8 wk compared favorably with a similar study by Chapman et al. (2016), wherein calves were fed 0.66 or up to $0.87 \mathrm{~kg} / \mathrm{d}$ of $\mathrm{DM}$ from MR and a $40 \%$ starch texturized CS. Digestion was measured at 52 to $56 \mathrm{~d}$ of age and calves were weaned at $49 \mathrm{~d}$. Similar to our data, Chapman et al. (2016) reported lower total-tract digestion of $\mathrm{DM}, \mathrm{OM}, \mathrm{ADF}, \mathrm{NDF}, \mathrm{CP}$, and fat when calves were fed greater amounts of MR.

Calves were bedded on long straw in the current study; we did not control or monitor consumption of straw, and straw intake could influence digestibility measurements. Voluntary intake of long straw used as bedding is not well documented. Castells et al. (2013) reported that calves consumed 15 and $3 \%$ of total dry feed intake as forage when offered chopped alfalfa or oat hay, respectively, for ad libitum consumption in separate buckets from 8 to $56 \mathrm{~d}$ of age. Intake was greater when calves were offered alfalfa compared with oat hay $(P<0.05)$. Castells et al. (2012) also reported that calves consumed $5 \%$ of total DMI as forage when offered chopped barley straw for ad libitum consumption from 8 to $71 \mathrm{~d}$ of age. Inclusion of forage sources (alfalfa hay, ryegrass hay, oat hay, barley straw, triticale silage, or corn silage) had no effect on DM, OM, or NDF digestibility measured at 64 to $69 \mathrm{~d}$ of age; however, CP digestion was greater when alfalfa, ryegrass, or corn silage was offered (Castells et al., 2012). Terré et al. (2015) reported that calves consumed 4 to $16 \%$ of their total dry feed intake as forage when offered chopped straw with pelleted or texturized calf starters before or after weaning. In studies by Castells et al. (2012, 2013) and Terré et al. (2015), hay sources were chopped and offered separately in buckets. Fokkink et al. (2011) offered long oat straw in buckets in addition to starter and reported that calves consumed $<1 \%$ of total dry feed intake as straw to from 0 to $56 \mathrm{~d}$ of the trial.

Total-tract starch digestion (Figure 3) increased with increasing nutrient intake. Natural logarithm of cumulative starch intake was the best predictor of total-tract starch digestion $(P<0.001)$ based on lowest BIC and AIC statistics. Total-tract starch digestion was also affected $(P<0.04)$ by CS composition. Neither MR nor $\mathrm{CS} \times \mathrm{MR}$ interaction was significant. Starch digestion increased more slowly with increasing starch intake in calves fed HSTEX, perhaps because a significant portion of the starch in HSTEX was provided in the whole grain portion of the starter. Approximately $97 \%$ of the starch in HSTEX was provided in the corn and oat grains and the remaining 3\% was in the pellet. Starch in LSPEL was provided primarily by wheat middlings. Thus, differences in starch type, starter form, and rate of starch fermentation and digestion could have contributed to observed differences in development of starch digestion. Alternatively, starch digestion at $8 \mathrm{wk}$ of age was uniformly above $95 \%$, suggesting that age contributed to development of total-tract starch digestion. Numerous workers have reported that production of pancreatic amylase was stimulated not by intake but also by age (Huber et al., 1961; Guilloteau et al., 1983, 2009), although Harmon (1993) suggested that $\alpha$-amylase production is influenced by energy intake and not carbohydrate intake per se. It should be noted that large intestinal fermentation of starch could also contribute to disappearance of starch and we did not determine contribution of small versus large intestinal disappearance of starch. However, data from Lallès et al. (1993) reported that $>91 \%$ of starch disappeared from the rumen in calves by 3 wk after ground grain was offered and calves were weaned. Approximately $7 \%$ of starch escaping the rumen disappears in the small intestine and $<2 \%$ disappears in the large intestine. More starch reached the duodenum when calves were fed diets containing pea protein versus soybean meal, suggesting botanical origin or processing affected site of starch disappearance (Lallès and Poncet, 1990; Lallès et al., 1993). Further data may be required to determine the extent to which diet form and composition may influence starch disappearance in young calves.

Total-tract NDF digestion (Figure 4) was influenced by the natural logarithm of cumulative NDF intake $(P$ 
$<0.0001)$ and MR intake $(P<0.006)$. Main effect of $\mathrm{CS}$ or $\mathrm{CS} \times \mathrm{MR}$ interaction was not significant. Calves fed MRM had higher NDF digestion at equal cumulative NDF intake, perhaps because calves fed MRM began consuming starter at an earlier age.

Cumulative intake of starch and NDF were best predictors of total-tract starch and NDF digestion, respectively, in our data set. It is possible that cumulative intake is a better indicator of the extent of rumen development, and, thus, preparation for weaning. Most weaning programs begin at a certain age; however, some researchers (e.g., Greenwood et al., 1997; Roth et al., 2008) have reported improved intake, growth, or health when calves were weaned when they reached a specific daily dry feed intake target. Our data suggest that cumulative, rather than a daily dry feed intake may be a more appropriate criterion for weaning strategies.

\section{CONCLUSIONS}

Growth and nutrient digestion were affected both by level of MR intake and CS formulation. Calves fed MRH grew faster and were more efficient to 8 wk but ate less CS and had higher fecal scores than calves fed MRM. Calves fed MRM began eating dry feed from an earlier age; therefore, digestion of DM, OM, CP, and fat at 5 wk were lower, as a greater proportion of total DMI was derived from CS, which was less digestible than MR. Conversely, digestion of ADF, NDF, and starch were greater at $5 \mathrm{wk}$ when calves were fed MRM, likely due to induction of rumen development. Also at 5 wk, digestion of DM, OM, ADF, CP, starch, and fat were lower in calves fed LSPEL versus HSTEX and may be associated with less digestible ingredients used in LSPEL. At 8 wk of age, digestion of DM, OM, $\mathrm{ADF}$, and NDF were lower in calves fed MRH, likely due to lower preweaning CS intake and delayed rumen development. Calves fed HSTEX had lower ADF and NDF digestion at $8 \mathrm{wk}$; however, the proportion of fiber in HSTEX was low and overall digestibility of DM and OM were higher in calves fed HSTEX due to starch digestibility $>95 \%$. Our data suggest that both level of MR feeding and CS should be considered when calves are fed large amount of MR.

\section{ACKNOWLEDGMENTS}

We are grateful to the Nurture Research Center farm staff and L. L. Deikun for assistance with animal care and sample and data collection. We also acknowledge W. Hu (Provimi) for assistance with statistical analyses. This research was funded wholly by Provimi North America (Brookville, $\mathrm{OH}$ ).

\section{REFERENCES}

AOAC International. 2000. Official Methods of Analysis. Vol. I 17th ed. AOAC Int., Arlington, VA.

Bach, A., A. Gimenez, J. L. Juaristi, and J. Ahedo. 2007. Effects of physical form of a starter for dairy replacement calves on feed intake and performance. J. Dairy Sci. 90:3028-3033.

Bach, A., M. Terré, and A. Pinto. 2013. Performance and health responses of dairy calves offered different milk replacer allowances. J. Dairy Sci. 96:7790-7797.

Baldwin, R. L. VI, K. R. McLeod, J. L. Klotz, and R. N. Heitmann. 2004. Rumen development, intestinal growth and hepatic metabolism in the pre- and postweaning ruminant. J. Dairy Sci. 87(E. Suppl.):E55-E65.

Ballou, M. A.. C. J. Cobb, T. J. Earleywine, and B. S. Obeidat. 2013. Breed and plane of milk replacer nutrition influence the performance of preweaned and postweaned dairy calves. Prof. Anim. Sci. 29:116-123.

Ballou, M. A., D. L. Hanson, C. J. Cobb, B. S. Obeidat, M. D. Sellers, A. R. Pepper-Yowell, J. A. Carroll, T. J. Earleywine, and S. D. Lawhon. 2015. Plane of nutrition influences the performance, innate leukocyte responses, and resistance to an oral Salmonella enterica serotype Typhimurium challenge in Jersey calves. J. Dairy Sci. 98:1972-1982.

Bjorklund, E. A., B. J. Heins, and H. Chester-Jones. 2013. Whole-milk feeding duration, calf growth, and profitability of group-fed calves in an organic production system. J. Dairy Sci. 96:7363-7370.

Bouchard, R., G. J. Brisson, and J. P. Julien. 1973. Nutritive value of bacterial sludge and whey powders for protein in calf milk replacers and on chromic oxide as indicator of digestibility. J. Dairy Sci. $56: 1445-1449$.

Byrne, C. J., S. Fair, A. English, D. Johnston, P. Lonergan, and D. Kenny. 2017. Effect of milk replacer and concentrate intake on growth rate, feeding behaviour and systemic metabolite concentrations of pre-weaned bull calves of two dairy breeds. Animal 11:1531-1538.

Castells, Ll., A. Bach, G. Araujo, C. Montoro, and M. Terré. 2012. Effect of different forage sources on performance and feeding behavior of Holstein calves. J. Dairy Sci. 95:286-293.

Castells, L., A. Bach, A. Aris, and M. Terré. 2013. Effects of forage provision to young calves on rumen fermentation and development of the gastrointestinal tract. J. Dairy Sci. 96:5226-5236.

Chapman, C. E., P. S. Erickson, J. D. Quigley, T. M. Hill, H. G. Bateman II, F. X. Suarez-Mena, and R. L. Schlotterbeck. 2016. Effect of milk replacer program on calf performance and digestion of nutrients with age of the dairy calf. J. Dairy Sci. 99:2740-2747.

Chapman, C. E., T. M. Hill, D. R. Elder, and P. S. Erickson. 2017. Nitrogen utilization, preweaning nutrient digestibility, and growth effects of Holstein dairy calves fed 2 amounts of a moderately high protein or conventional milk replacer. J. Dairy Sci. 100:279-292.

Coverdale, J. A., H. D. Tyler, J. D. Quigley III, and J. A. Brumm. 2004. Effect of various levels of forage and form of diet on rumen development and growth in calves. J. Dairy Sci. 87:2554-2562.

Davis Rincker, L. E., M. J. VandeHaar, C. A. Wolf, J. S. Liesman, L. T. Chapin, and M. S. Weber Nielsen. 2011. Effect of intensified feeding of heifer calves on growth, pubertal age, calving age, milk yield, and economics. J. Dairy Sci. 94:3554-3567.

de Passillé, A. M., T. F. Borderas, and J. Rushen. 2011. Weaning age of calves fed a high milk allowance by automated feeders: Effects on feed, water, and energy intake, behavioral signs of hunger, and weight gains. J. Dairy Sci. 94:1401-1408.

Diaz, M. C., M. E. Van Amburgh, J. M. Smith, J. M. Kelsey, and E. L. Hutten. 2001. Composition of growth of Holstein calves fed milk replacer from birth to 105-kilogram body weight. J. Dairy Sci. 84:830-842.

Dubois, M., K. A. Gilles, J. K. Hamilton, P. A. Rebers, and F. Smith. 1956. Colorimetric method for determination of sugars and related substances. Anal. Chem. 28:350-356.

Eckert, E., H. E. Brown, K. E. Leslie, T. J. DeVries, and M. A. Steele. 2015. Weaning age affects growth, feed intake, gastrointestinal de- 
velopment, and behavior in Holstein calves fed an elevated plane of nutrition during the preweaning stage. J. Dairy Sci. 98:6315-6326.

FASS. 2010. Guide for the Care and Use of Agricultural Animals in Agricultural Research and Teaching. 3rd ed. Federation of Animal Science Societies, Champaign, IL.

Flatt, W. P., R. G. Warner, and J. K. Loosli. 1958. Influence of purified materials on the development of the ruminant stomach. J. Dairy Sci. 41:1593-1600.

Fokkink, W. B., T. M. Hill, H. G. Bateman II, J. M. Aldrich, R. L. Schlotterbeck, and A. F. Kertz. 2011. Case Study: Effect of high and low-cereal-grain starters on straw intake and rumen development of neonatal Holstein calves. Prof. Anim. Sci. 27:357-364.

Greenwood, R. H., J. L. Morrill, and E. C. Titgemeyer. 1997. Using dry feed intake as a percentage of initial body weight as a weaning criterion. J. Dairy Sci. 80:2542-2546.

Guilloteau, P., T. Corring, P. Garnot, P. Martin, R. Toullec, and G. Durand. 1983. Effects of age and weaning on enzyme activities of abomasum and pancreas of the lamb. J. Dairy Sci. 66:2373-2385.

Guilloteau, P., R. Zabielski, and J. W. Blum. 2009. Gastrointestinal tract and digestion in the young ruminant: Ontogenesis, adaptations, consequences and manipulations. J. Physiol. Pharmacol. 60(Suppl. 3):37-46.

Hall, M. B. 2009. Analysis of starch, including maltooligosaccharides, in animal feeds: A comparison of methods and a method recommended for AOAC collaborative study. J. AOAC Int. 92:42-49.

Harmon, D. L. 1993. Nutritional regulation of postruminal digestive enzymes in ruminants. J. Dairy Sci. 76:2102-2111.

Hill, T. M., H. G. Bateman II, J. M. Aldrich, and R. L. Schlotterbeck. 2010. Effect of milk replacer program on digestion of nutrients in dairy calves. J. Dairy Sci. 93:1105-1115.

Hill, T. M., J. D. Quigley, F. X. Suarez-Mena, H. G. Bateman II, and R. L. Schlotterbeck. 2016. Effect of milk replacer feeding rate and functional fatty acids on dairy calf performance and digestion of nutrients. J. Dairy Sci. 99:6352-6361.

Howarth, R. E., R. L. Baldwin, and M. Ronning. 1968. Enzyme activities in liver, muscle, and adipose tissue of calves and steers. J. Dairy Sci. 51:1270-1274.

Huber, J. T. 1969. Development of the digestive and metabolic apparatus of the calf. J. Dairy Sci. 52:1303-1315.

Huber, J. T., N. L. Jacobson, R. S. Allen, and P. A. Hartman. 1961. Digestive enzyme activities in the young calf. J. Dairy Sci. 44:1494-1501.

Jasper, J., and D. M. Weary. 2002. Effects of ad libitum milk intake on dairy calves. J. Dairy Sci. 85:3054-3058.

Kertz, A. F., and H. Chester-Jones. 2004. Invited review: Guidelines for measuring and reporting calf and heifer experimental data. J. Dairy Sci. 87:3577-3580.

Lallès, J. P., S. Pochet, and C. Poncet. 1993. Ruminal and post-ruminal digestion of starch from 2 types of concentrates in the young calf during and after weaning. Ann. Zootech. 42:168.

Lallès, J. P., and C. Poncet. 1990. Changes in ruminal and intestinal digestion during and after weaning in dairy calves fed concentrate diets containing pea or soya bean meal. 1. Digestion of organic matter and nitrogen. Livest. Prod. Sci. 24:129-142.

Meale, S. J., L. N. Leal, J. Martín-Tereso, and M. A. Steele. 2015. Delayed weaning of Holstein bull calves fed an elevated plane of nutrition impacts feed intake, growth and potential markers of gastrointestinal development. Anim. Feed Sci. Technol. 209:268-273.

Moallem, U., D. Werner, H. Lehrer, M. Zachut, L. Livshitz, S. Yakoby, and A. Shamay. 2010. Long- term effects of ad libitum whole milk prior to weaning and prepubertal protein supplementation on skeletal growth rate and first-lactation milk production. J. Dairy Sci. 93:2639-2650.

Nejad, J. G., N. Torbatinejad, A. A. Naserian, S. Kumar, J. D. Kim, Y. H. Song, C. S. Ra, and K. I. Sung. 2012. Effects of process- ing of starter diets on performance, nutrient digestibility, rumen biochemical parameters and body measurements of Brown Swiss dairy calves. Asian-Australas. J. Anim. Sci. 25:980-987.

NRC. 2001. Nutrient Requirements of Dairy Cattle. 7th rev. ed. Natl. Acad. Sci., Washington, DC.

Osorio, J. S., R. L. Wallace, D. J. Tomlinson, T. J. Earleywine, M. T. Socha, and J. K. Drackley. 2012. Effects of source of trace minerals and plane of nutrition on growth and health of transported neonatal dairy calves. J. Dairy Sci. 95:5831-5844.

Porter, J. C., R. G. Warner, and A. F. Kertz. 2007. Effect of fiber level and physical form of starter on growth and development of dairy calves fed no forage. Prof. Anim. Sci. 23:395-400.

Quigley, J. D., T. M. Hill, L. L. Deikun, and R. L. Schlotterbeck. 2017. Effects of amount of colostrum replacer, amount of milk replacer, and housing cleanliness on health, growth and intake of Holstein calves to eight weeks of age. J. Dairy Sci. 100:9177-9185.

Quigley, J. D., T. A. Wolfe, and T. H. Elsasser. 2006. Effects of additional milk replacer feeding on calf health, growth, and selected blood metabolites in calves. J. Dairy Sci. 89:207-216.

Robertson, J. B., and P. J. Van Soest. 1981. The Detergent System of Analysis and its Application to Human Foods. Cornell University, Ithaca, NY

Rosenberger, K., J. H. C. Costa, H. W. Neave, M. A. G. von Keyserlingk, and D. M. Weary. 2017. The effect of milk allowance on behavior and weight gains in dairy calves. J. Dairy Sci. 100:504-512.

Roth, B. A., E. Hillmann, M. Stauffacher, and N. M. Keil. 2008. Improved weaning reduces cross-sucking and may improve weight gain in dairy calves. Appl. Anim. Behav. Sci. 111:251-261.

Roth, B. A., N. M. Keil, L. Gygax, and E. Hillmann. 2009. Influence of weaning method on health status and rumen development in dairy calves. J. Dairy Sci. 92:645-656.

Sander, E. G., R. G. Warner, and H. N. Harrison. 1959. The stimulatory effect of sodium butyrate and sodium propionate on the development of rumen mucosa in the young calf. J. Dairy Sci. 42:1600-1605

Sweeney, B. C., C. J. Rushen, D. M. Weary, and A. M. de Passillé 2010. Duration of weaning, starter intake, and weight gain of dairy calves fed large amounts of milk. J. Dairy Sci. 93:148-152.

Terré, M., Ll. Castells, M. A. Khan, and A. Bach. 2015. Interaction between the physical form of the starter feed and straw provision on growth performance of Holstein calves. J. Dairy Sci. 98:1101-1109.

Terré, M., M. Devant, and A. Bach. 2007. Effect of level of milk replacer fed to Holstein calves on performance during the preweaning period and starter digestibility at weaning. Livest. Sci. 110:82-88.

USDA. 2016. Dairy 2014, Dairy Cattle Management Practices in the United States, 2014. USDA-APHIS-VS-CEAH-NAHMS. Fort Collins, CO.

Van Keulen, J. V., and B. A. Young. 1977. Evaluation of acid insoluble ash as a natural marker in ruminant digestibility studies. J. Anim. Sci. 44:282-287.

Van Soest, P. J., J. B. Robertson, and B. A. Lewis. 1991. Methods for dietary fiber, neutral detergent fiber, non-starch polysaccharides in relation to animal nutrition. Symposium: carbohydrate methodology, metabolism and nutritional implications in dairy cattle. J. Dairy Sci. 74:3583-3597.

Wildman, E. E., G. M. Jones, P. E. Wagner, R. L. Bowman, H. F Troutt Jr., and T. N. Lesch. 1982. A dairy cow body condition scoring system and its relationship to selected production characteristics. J. Dairy Sci. 65:495-501.

Yunta, C., M. Terré, and A. Bach. 2015. Short- and medium-term changes in performance and metabolism of dairy calves offered different amounts of milk replacers. Livest. Sci. 181:249-255. 